\title{
Clinicopathological Features of Pancreatic Adenosquamous Carcinoma and Undifferentiated Carcinoma: A case series
}

\author{
Shinjiro Kobayashi ${ }^{1}$, Takashi Fujino ${ }^{2}$, Kouhei Segam ${ }^{1}$, Hiroyuki Hoshino ${ }^{1}$, \\ Ryuichi Oshima ${ }^{1}$, Masafumi Katayama ${ }^{1}$, Satoshi Koizumi ${ }^{1}$, Kazunari Nakahara ${ }^{3}$, \\ Nobuyuki Ohike ${ }^{4}$, and Takehito Otsubo ${ }^{1}$
}

(Received for Publication: May 10, 2016)

\begin{abstract}
Adenosquamous carcinoma(ASqC) and undifferentiated carcinoma(UC) of the pancreas are rare, and thus we do not clearly know their biological characteristics. We therefore conducted a clinicopathological study of 17 patients with $\mathrm{ASqC}$ or UC to investigate their clinical features, imaging findings, histopathological findings of resected specimens, and prognostic factors. The subjects were 9 patients $(11.1 \%)$ with $\mathrm{ASqC}$ and $8(9.9 \%)$ with UC among 81 patients with invasive ductal carcinoma. Mean survival time was $16.3 \pm 5.0$ months in the patients with $\mathrm{ASqC}$ and $12.4 \pm 5.6$ months in those with UC. Analysis of prognostic factors revealed that survival was shorter in the patients with confluent multinodular type than in those with simple nodular type (5.0 \pm 2.4 vs. $18.4 \pm 4.8$ months, $P=0.039)$ in patients with stage IVb rather than stage III or IVa cancer $(6.2 \pm 2.9$ vs. $19.4 \pm 5.2$ months, $P=0.026$ ). Survival tended to be slightly shorter in patients who had recurrence within 6 months. Histopathological findings of immunostaining revealed that all 17 patients were positive with CK7 (a marker for adenocarcinoma) in all 17 patients. ASqC and UC were suggested to be differentiated from adenocarcinoma. They are known to have a poorer outcome than common pancreatic cancer, but may be associated with a relatively good outcome in some patients.
\end{abstract}

\section{Key words}

Pancreatic cancer, pancreatic adenosquamous carcinoma, pancreatic undifferentiated carcinoma

\section{Introduction}

Among the epithelial malignancies that occur in the pancreas, adenosquamous carcinoma (ASqC) (incidence, $0.38-4 \%)^{1-3)}$ and undifferentiated carcinoma (UC) (incidence, $2-7 \%)^{4-6}$ are relatively rare. Thus we do not clearly know their biological characteristics. To investigate their histogenesis and clinical features, we conducted a clinicopathological study of 17 patients with $\mathrm{ASqC}$ or UC treated at the St. Marianna University School of Medicine.

\section{Methods}

Eighty-one patients with ductal adenocarcinoma of the pancreas were treated at our hospital between April 2005 and January 2014. Of them, 9 (11.1\%) with $\mathrm{ASqC}$ and 8 (9.9\%) with UC (17 patients in total) were retrospectively studied clinicopathologically (Table 1). These patients were all Japanese, and comprised 12 men and 5 women aged between 37 and 86 years (mean, $66.3 \pm 12.5$ years; median, 71 years). The mean age of the patients with $\mathrm{ASqC}$ was $72 \pm 7.1$

1 Department of Gastroenterological and General Surgery, St. Marianna University School of Medicine

2 Department of Pathology, St. Marianna University School of Medicine

3 Department of Hepatic Medicine, St. Marianna University School of Medicine

4 Department of Pathology, Showa University Northern Yokohama Hospital

Conflict of interest statement: Shinjiro Kobayashi and the other co-authors have no conflicts of interest to declare. 
Table 1. Basic Characteristics of Patients

\begin{tabular}{|c|c|c|c|c|c|}
\hline Case No. & Pathology & Age/sex & Location & Size $(\mathrm{mm})$ & $\begin{array}{l}\text { CA19-9 } \\
(\mathrm{U} / \mathrm{ml})\end{array}$ \\
\hline 1 & & $74 / \mathrm{F}$ & Head & 30 & 483 \\
\hline 2 & & $76 / \mathrm{M}$ & Head & 33 & 86.5 \\
\hline 3 & & $74 / \mathrm{M}$ & Head & 55 & 551.2 \\
\hline 4 & & $75 / \mathrm{F}$ & Head & 40 & 8325.9 \\
\hline 5 & Adenosquamous carcinoma & $61 / \mathrm{M}$ & Tail & 50 & 947.8 \\
\hline 6 & & $59 / \mathrm{M}$ & Tail & 100 & 7.7 \\
\hline 7 & & $72 / \mathrm{M}$ & Tail & 53 & 96.1 \\
\hline 8 & & $79 / \mathrm{M}$ & Head & 18 & 52.9 \\
\hline 9 & & $78 / \mathrm{M}$ & Tail & 10 & 38.5 \\
\hline 10 & & $62 / \mathrm{M}$ & Tail & 50 & 47.2 \\
\hline 11 & & $51 / \mathrm{M}$ & Head & 25 & 178 \\
\hline 12 & & $54 / \mathrm{F}$ & Tail & 100 & 1.6 \\
\hline 13 & Undifferentiated carcinoma & $56 / \mathrm{F}$ & Body & 45 & 10919.7 \\
\hline 14 & & $37 / \mathrm{F}$ & Head & 40 & 135 \\
\hline 15 & & $71 / \mathrm{M}$ & Tail & 70 & 10 \\
\hline 16 & & $86 / \mathrm{M}$ & Body & 50 & 66.1 \\
\hline 17 & & $63 / \mathrm{M}$ & Body & 45 & 15 \\
\hline
\end{tabular}

F: female, $M$ : male

years whereas that of the patients with UC was $60 \pm 14.5$ years, indicating that the patients with UC were younger. The following items investigated: (1) computed tomography (CT) findings (morphological type, contrast enhancement, and presence or absence of cystic component), (2) histopathological findings, (3) clinical course (such as site of recurrence after surgery, and survival.), and (4) survival classified by several factors (histological type, tumor size, preoperative CA19-9 level, morphological type determined by $\mathrm{CT}$, presence or absence of cystic component, infiltration pattern, stage, and timing of recurrence). In relation to tumor size and preoperative CA19-9 level, survival was compared between patients with values of not less than and below the median values of tumor size and CA19-9 level. We obtained approval of the St. Marianna University School of Medicine Ethics Committee (approval number:3156).

\section{CT protocols and findings}

Seventeen patients underwent triple-phase CT imaging during the unenhanced, pancreatic and portal venous phase. CT scanning was performed using an Aquilion system (Toshiba Medical Systems Corp., Tokyo, Japan). A section thickness of $2 \mathrm{~mm}$ with reconstruction interval of $2 \mathrm{~mm}$, field of view of 300 $370 \mathrm{~mm}$, a gantry rotation time of $0.5 \mathrm{~s}$, tube current of $150-200 \mathrm{~mA}$, and peak voltage of $120 \mathrm{kVp}$ were used. For the 64-detector CT scanner, we used detector collimation of $0.75 \mathrm{~mm}$ and table speed of 12.0 $\mathrm{mm}$ per rotation. For multiphase imaging, $300 \mathrm{mg}$ $\mathrm{I} / \mathrm{ml}$ of nonionic contrast material (iopromide injection FRI, FUJIFILM RI Pharma Co., Ltd., Tokyo, Japan) was administered. A fixed dose of $1.5 \mathrm{ml}$ iopromide per kilogram body weight was administered at a rate of 2-3 ml/s. The scanning time was early (at 35$45 \mathrm{~s}$ ) for the unenhanced phase, and delayed (at 70- 


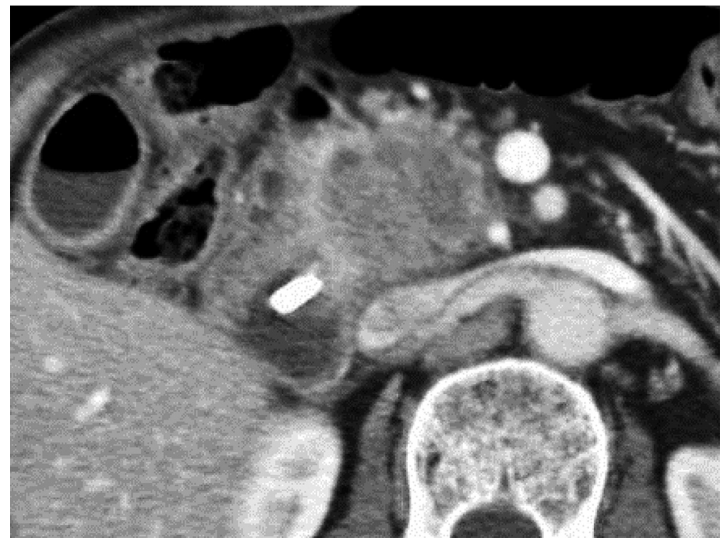

Fig. 1. Simple nodular type: a single spherical tumor showing expansive growth.

$80 \mathrm{~s})$ for the pancreatic and portal venous phases. following administration of the contrast material.

To determine the morphological type of tumor from the CT findings, delayed-phase images of the pancreas were examined by two radiologists and one gastrointestinal surgeon specializing in the pancreas, and consensus was reached. Simple nodular type (Fig. 1) was defined as a single spherical tumor showing expansive growth. Confluent multinodular type (Fig. 2) was defined as a tumor comprised of confluent nodules.

\section{Preparation of histopathological specimens}

To prepare histopathological specimens, the tissue was fixed in $10 \%$ formalin, embedded in paraffin, and sliced at 5-mm intervals for whole-section analysis. Specimens from all patients were subjected to immunostaining with CK7 and CK14.

\section{Statistical analysis}

Data are expressed as mean \pm standard deviation. Survival of patients classified by several factors was compared by log rank test using Kaplan-Meier survival curves. A $P$-value $<0.05$ was considered statistically significant.

\section{Results}

\section{Imaging findings}

On CT images, 13 patients had a simple nodular tumor and 4 patients ( 2 with $\mathrm{ASqC}$ and another 2 with UC) had a confluent multinodular tumor (Table 2). In $5(55.6 \%)$ of the 9 patients with $\mathrm{ASqC}$, the tumor was rather strongly enhanced, but it was not strongly enhanced in any of the patients with UC.

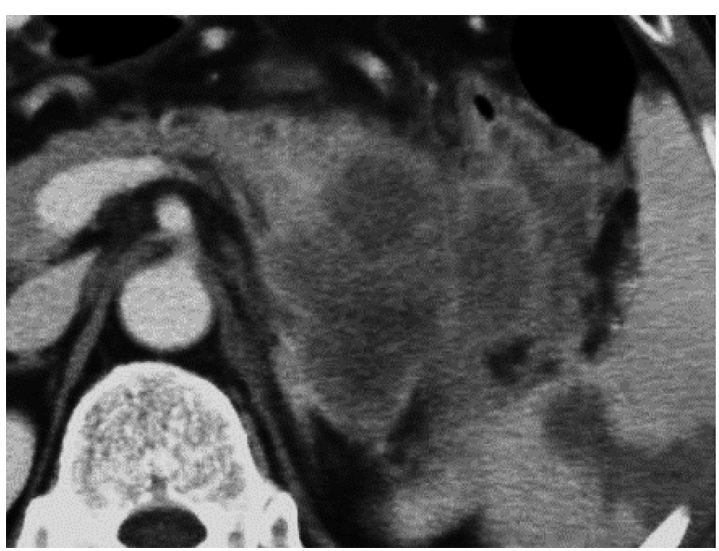

Fig. 2. Confluent multinodular type: an irregularly shaped tumor comprised of more than one confluent nodule.

Five (55.6\%) of the 9 patients with $\mathrm{ASqC}$ and 4 $(50 \%)$ of the 8 patients with UC had a cystic component within the tumor (Fig. 3).

\section{Histopathological findings}

In patients with $\mathrm{ASqC}$, the squamous carcinoma component accounted for $40 \%$ to a maximum of $60 \%$ of the tumor (Table 3). Of the patients with UC, 5 had the pleomorphic type and 3 had the osteoclastlike giant cell type. The infiltration pattern was $\beta$ in all patients with UC, whereas it was $\beta$ in 4 patients and $\gamma$ in 5 patients with ASqC. In all 17 patients (9 with $\mathrm{ASqC}$ and 8 with $\mathrm{UC}$ ), cells were positive for CK7, a staining marker for adenocarcinoma (Fig. 4a, b). CK14 staining was positive in 8 of the 9 patients with $\mathrm{ASqC}$ and in 5 of the 8 patients with UC (Fig. 5a-c).

\section{Clinical course}

All 17 patients had advanced cancers (stage III or higher); 9 cancers were stage III, 3 were stage IVa, and 5 were stage IVb (Table 4). Of the 13 patients who underwent surgery, 6 (4 of the 8 patients with $\mathrm{ASqC}$ and 2 of the 5 patients with UC) had a recurrence within 6 months of surgery. Recurrence in these 6 patients was in the liver. Two patients with $\mathrm{ASqC}$ and one patient with UC survived for 2 years or more.

\section{Comparison of survival according to several factors}

Survival was compared between patients classified by histological type, tumor size, preoperative CA19-9 level, morphological type determined by CT, presence or absence of a cystic component, infiltra- 
Table 2. CT Findings

\begin{tabular}{|c|c|c|c|c|}
\hline Case No. & Pathology & Morphological type & Enhancement pattern/degree & Cystic component \\
\hline 1 & & Simple nodular type & Heterogeneous/progressive & Negative \\
\hline 2 & & Simple nodular type & Heterogeneous/progressive & Positive \\
\hline 3 & & Simple nodular type & Heterogeneous/progressive & Positive \\
\hline 4 & & Simple nodular type & Heterogeneous/progressive & Positive \\
\hline 5 & Adenosquamous carcinoma & Confluent multinodular type & Heterogeneous/moderate & Positive \\
\hline 6 & & Confluent multinodular type & Heterogeneous/moderate & Positive \\
\hline 7 & & Simple nodular type & Homogeneous/regressive & Negative \\
\hline 8 & & Simple nodular type & Homogeneous/regressive & Negative \\
\hline 9 & & Simple nodular type & Homogeneous/progressive & Negative \\
\hline 10 & & Simple nodular type & Homogeneous/regressive & Negative \\
\hline 11 & & Simple nodular type & Heterogeneous/regressive & Negative \\
\hline 12 & & Simple nodular type & Heterogeneous/moderate & Positive \\
\hline 13 & Undifferentiated carcinoma & Simple nodular type & Homogeneous/regressive & Negative \\
\hline 14 & & Simple nodular type & Heterogeneous/moderate & Positive \\
\hline 15 & & Confluent multinodular type & Heterogeneous/moderate & Positive \\
\hline 16 & & Confluent multinodular type & Heterogeneous/moderate & Positive \\
\hline 17 & & Simple nodular type & Homogeneous/regressive & Negative \\
\hline
\end{tabular}

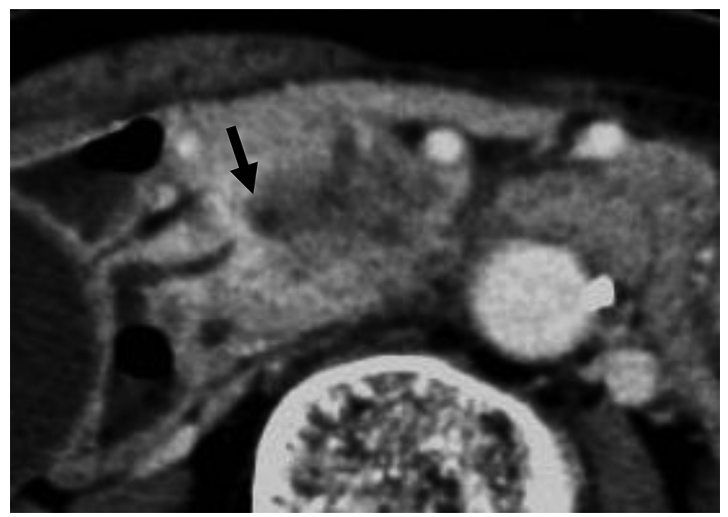

Fig. 3. Cystic component inside the tumor $(\rightarrow)$.

tion pattern, stage, and timing of recurrence (Table 5). Mean survival time was $16.3 \pm 5.0$ months in the patients with $\mathrm{ASqC}$ and $12.4 \pm 5.6$ months in those with UC $(P=0.621)$. No significant difference in survival was observed with respect to tumor size, preoperative CA19-9 level, or infiltration pattern. However, survival was shorter in patients with a confluent multinodular tumor than in those with a simple nodular tumor $(5.0 \pm 2.4$ vs. $18.4 \pm 4.8$ months, $P=0.039)$, and in patients in stage IVb rather than stage III or Iva cancer $(6.2 \pm 2.9$ vs. $19.4 \pm 5.2$ months, $P=0.026)$. Survival tended to be slightly shorter in the patients who had recurrence within 6 months $(P=0.059)$.

\section{Discussion}

Invasive ductal carcinoma accounts for the majority of pancreatic malignant neoplasms and has a poor prognosis except in a series of highly selected patients undergoing radical surgical therapy for cure. $\mathrm{ASqC}$ and $\mathrm{UC}$ are unusual variant of pancreatic neoplasms. Histologically, pancreatic ASqC is distin- 
Table 3. Pathologic Findings

\begin{tabular}{|c|c|c|c|c|c|c|}
\hline $\begin{array}{l}\text { Case } \\
\text { No. }\end{array}$ & Pathology & $\begin{array}{l}\text { Squamou } \\
\text { s } \\
\text { cells }(\%)\end{array}$ & $\begin{array}{l}\text { Classification of } \\
\text { undifferentiated carcinoma }\end{array}$ & $\begin{array}{l}\text { INF } \\
\text { patter } \\
\text { n }\end{array}$ & CK7 staining & CK14 staining \\
\hline 1 & & 60 & - & $\gamma$ & $\begin{array}{l}\text { Many adenocarcinoma cells were } \\
\text { positive }\end{array}$ & $\begin{array}{l}\text { Many squamous cells were } \\
\text { positive }\end{array}$ \\
\hline 2 & & 40 & - & $\beta$ & $\begin{array}{l}\text { Many adenocarcinoma cells were } \\
\text { positive }\end{array}$ & $\begin{array}{l}\text { Some squamous cells were } \\
\text { positive }\end{array}$ \\
\hline 3 & $\begin{array}{l}\text { Adenosquamous } \\
\text { carcinoma }\end{array}$ & 50 & - & $\gamma$ & $\begin{array}{l}\text { Many adenocarcinoma cells were } \\
\text { positive }\end{array}$ & Negative \\
\hline 4 & & 40 & - & $\gamma$ & $\begin{array}{l}\text { Many adenocarcinoma cells were } \\
\text { positive }\end{array}$ & $\begin{array}{l}\text { Many squamous cells were } \\
\text { positive }\end{array}$ \\
\hline 5 & & 40 & - & $\beta$ & Only a few cells were positive & $\begin{array}{l}\text { Many squamous cells were } \\
\text { positive }\end{array}$ \\
\hline 6 & & 50 & - & $\beta$ & $\begin{array}{l}\text { Many adenocarcinoma cells were } \\
\text { positive }\end{array}$ & $\begin{array}{l}\text { Some squamous cells were } \\
\text { positive }\end{array}$ \\
\hline 7 & & 40 & - & $\beta$ & $\begin{array}{l}\text { Many adenocarcinoma cells were } \\
\text { positive }\end{array}$ & $\begin{array}{l}\text { Many squamous cells were } \\
\text { positive }\end{array}$ \\
\hline 8 & & 40 & - & $\gamma$ & $\begin{array}{l}\text { Many adenocarcinoma cells were } \\
\text { positive }\end{array}$ & $\begin{array}{l}\text { Many squamous cells were } \\
\text { positive }\end{array}$ \\
\hline 9 & & 40 & - & $\gamma$ & $\begin{array}{l}\text { Many adenocarcinoma cells were } \\
\text { positive }\end{array}$ & $\begin{array}{l}\text { Many squamous cells were } \\
\text { positive }\end{array}$ \\
\hline 10 & & 30 & $\begin{array}{l}\text { Pleomorphic type, spindle cell } \\
>\text { adenosquamous }>\text { poor }\end{array}$ & $\beta$ & $\begin{array}{l}\text { Many adenocarcinoma cells were } \\
\text { positive }\end{array}$ & $\begin{array}{l}\text { Some squamous cells were } \\
\text { positive }\end{array}$ \\
\hline 11 & & 1 & $\begin{array}{l}\text { Osteoclast-like giant cell type, } \\
\text { spindle cell type }\end{array}$ & $\beta$ & $\begin{array}{l}\text { Many adenocarcinoma cells were } \\
\text { positive }\end{array}$ & Some cells were positive \\
\hline 12 & Undifferentiated & / & $\begin{array}{l}\text { Osteoclast-like giant cell type, } \\
\text { spindle cell type }\end{array}$ & $\beta$ & $\begin{array}{l}\text { Many adenocarcinoma cells were } \\
\text { positive }\end{array}$ & Negative \\
\hline 13 & carcinoma & l & Pleomorphic type & $\beta$ & $\begin{array}{l}\text { Many adenocarcinoma cells were } \\
\text { positive }\end{array}$ & Negative \\
\hline 14 & & l & Osteoclast-like giant cell type & $\beta$ & $\begin{array}{l}\text { Many adenocarcinoma cells were } \\
\text { positive }\end{array}$ & Negative \\
\hline 15 & & / & Pleomorphic type & $\beta$ & Diffusely positive & A few cells were positive \\
\hline 16 & & / & Pleomorphic type & $\beta$ & Diffusely positive & Some cells were positive \\
\hline 17 & & I & Pleomorphic type & $\beta$ & Many cells were positive & A few cells were positive \\
\hline
\end{tabular}

$I N F$ : infiltration, $C K 7$ : cytokeratin 7,CK14: cytokeratin 14, poor: poorly differentiated adenocarcinoma 
a
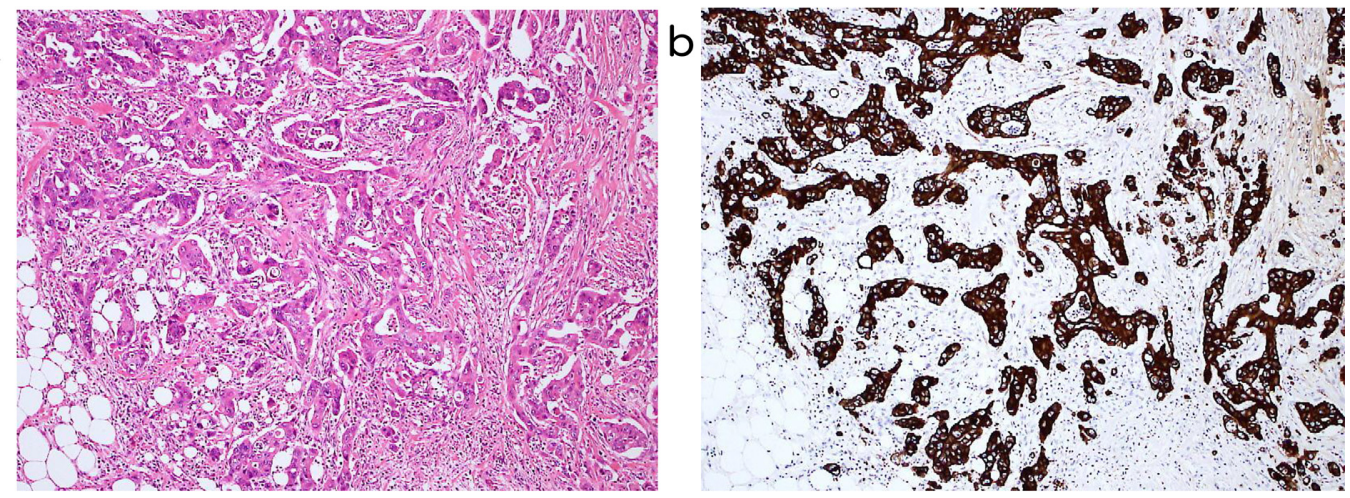

Fig. 4. Hematoxylin and eosin (HE) staining of undifferentiated carcinoma (a). The tumor was positive for CK7, a staining marker for adenocarcinoma (b).

a
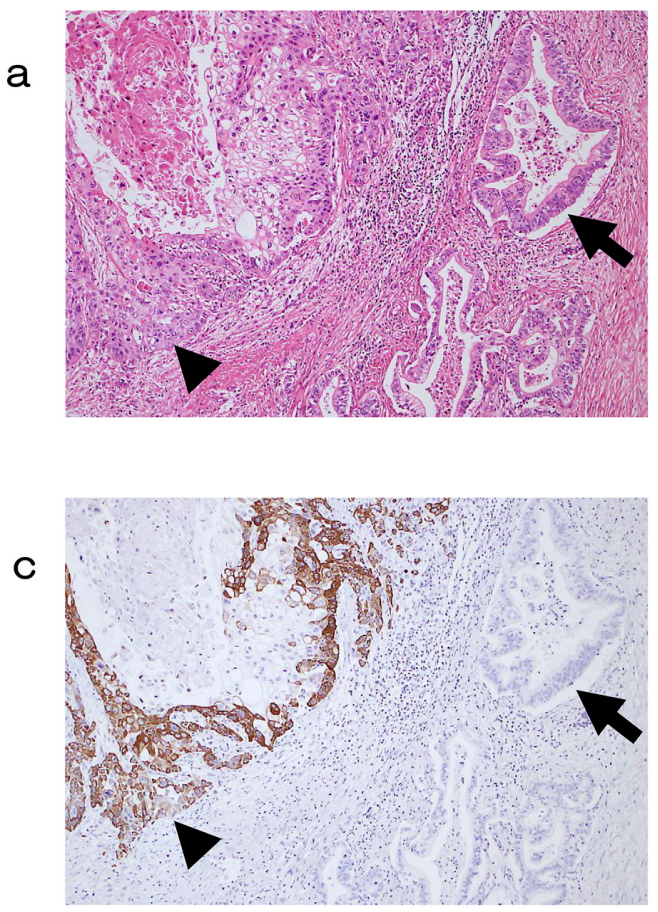

guished from ductal adenocarcinoma of the pancreas by the presence of $30 \%$ or more malignant squamous cells ${ }^{788)}$. ASqC often presents with exophytic growth and has greater vascularity than common ductal carcinoma ${ }^{9}$. In a large tumor of this type of carcinoma, contrast tends to be poorly enhanced in the center due to internal necrosis or cyst formation ${ }^{10) 11}$. In patients with pancreatic $\mathrm{ASqC}$ who underwent surgical resection, median survival was reported to be 6 to 14.4 months, indicating a poor prognosis ${ }^{12-14)}$. Boyd et al. analyzed 415 patients with $\mathrm{ASqC}$ and reported that their 2-year survival was $10.8 \%{ }^{15}$. Histologically,

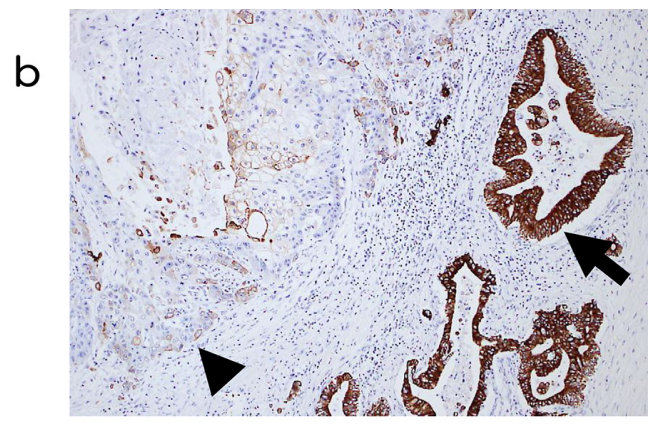

Fig. 5. HE staining of adenosquamous carcinoma (a). The adenocarcinoma component (arrow) and squamous cell carcinoma component (arrow-head) were mixed. The adenocarcinoma component was positive for $\mathrm{CK} 7$, whereas the squamous cell carcinoma component was only slightly positive for CK7 (b). The squamous cell carcinoma component was strongly positive for CK14 (c).

$\mathrm{ASqC}$ is presumed to arise from malignant transformation of the heterotopic squamous epithelium ${ }^{1112)}$, direct malignant transformation of adenocarcinoma to squamous carcinoma ${ }^{16) 17)}$, or other mechanisms. Presently, direct malignant transformation of adenocarcinoma to squamous carcinoma is considered to be the dominant mechanism.

UC was first reported by Sommers and Meissner in 1954 as pancreatic ductal carcinoma (pleomorphic carcinoma) mixed with a sarcomatoid component ${ }^{18)}$. As in the case of $\mathrm{ASqC}, \mathrm{UC}$ is characterized by expansive growth, hypervascularity, and intratumoral 
Table 4. Clinical Course

\begin{tabular}{|c|c|c|c|c|c|c|c|}
\hline $\begin{array}{l}\text { Case } \\
\text { No. }\end{array}$ & Pathology & Stage & Therapy & $\begin{array}{c}\text { Adjyuvant } \\
\text { therapy }\end{array}$ & $\begin{array}{l}\text { Recurrence } \\
\text { (months) }\end{array}$ & Location of metastasis & $\begin{array}{l}\text { Survival } \\
\text { (months) }\end{array}$ \\
\hline 1 & & $\mathrm{IVb}$ & PD & TS-1 & 1.5 & Liver & 11 \\
\hline 2 & & IVa & PD & TS-1 & 7 & Liver & 28 \\
\hline 3 & & III & PD & None & 6 & Liver & 33 \\
\hline 4 & & III & $\mathrm{PD}$ & None & 1 & Liver & 3 \\
\hline 5 & Adenosquamous & $\mathrm{IVb}$ & Chemo & I & I & I & 2 \\
\hline 6 & & III & DP & TS-1 & 6 & Local & 12 \\
\hline 7 & & III & DP & TS-1 & No recurrence & I & 9 (alive) \\
\hline 8 & & IVa & PD & None & No recurrence & l & 5 (alive) \\
\hline 9 & & III & DP & None & No recurrence & l & 1 (alive) \\
\hline 10 & & III & DP & None & 3 & Liver & 4 \\
\hline 11 & & III & PD & None & 1 & Liver, lung, lymph node & 5 \\
\hline 12 & & III & DP & TS-1 & 7 & Lung & 20 \\
\hline 13 & Undifferentiated & $\mathrm{IVb}$ & DP & TS-1 & 7 & Dissemination & 15 \\
\hline 14 & carcinoma & III & PD & TS-1 & 36 & Remnant pancreas & 48 \\
\hline 15 & & IVa & BSC & I & l & I & 4 \\
\hline 16 & & IVb & $\mathrm{BSC}$ & I & I & I & 2 \\
\hline 17 & & IVb & BSC & I & 1 & 1 & 1 \\
\hline
\end{tabular}

PD: pancreaticoduodenectomy, Chemo: chemotherapy, DP: distal pancreatectomy, BSC: best

hemorrhage or necrosis ${ }^{19}$. Paal et al. studied 35 patients with UC and reported a mean postoperative survival time of 3.3 months in patients with spindle cell tumor $(n=4)$ and 6.0 months in those with giant cell tumor $(n=31)^{4}$. WHO classifies giant cell tumor, pleomorphic tumor, and spindle cell tumor as UC and osteoclast-like giant cell tumor as UC with osteoclast-like giant cells, differentiating the former three types from the latter based on their clinical features. The reason is that UC is considered to be of epithelial origin and arises from sarcomatoid metaplasia of invasive ductal carcinoma, whereas UC with osteoclast-like giant cells is considered to be of mesenchymal origin and has a relatively good outcome. However, in a recent study of patients with early osteoclast-like giant cell tumors, Bergmann et al. reported that an initial carcinogenesis of epithelial origin associated with a PanIN3 lesion was found in patients with osteoclast-like giant cell tumors ${ }^{20)}$. Thus, the general conclusion seems to be that osteoclastlike giant cell tumors also originate from epithelial cells ${ }^{2021)}$. Maksymov et al. discussed the possibility of neoplastic changes in a part of the epithelium, with cells transitionally differentiating into myoepithelial (mesenchymal) cells, and explained the diversity of the epithelial component of osteoclast-like giant cell tumors $^{22}$. In the present study, we performed immunostaining of the lesions of 17 patients with two particular types of pancreatic cancer to determine their histogenesis. CK7 staining was positive in all patients 
Table 5. Patient Survival Classified by Several Factors

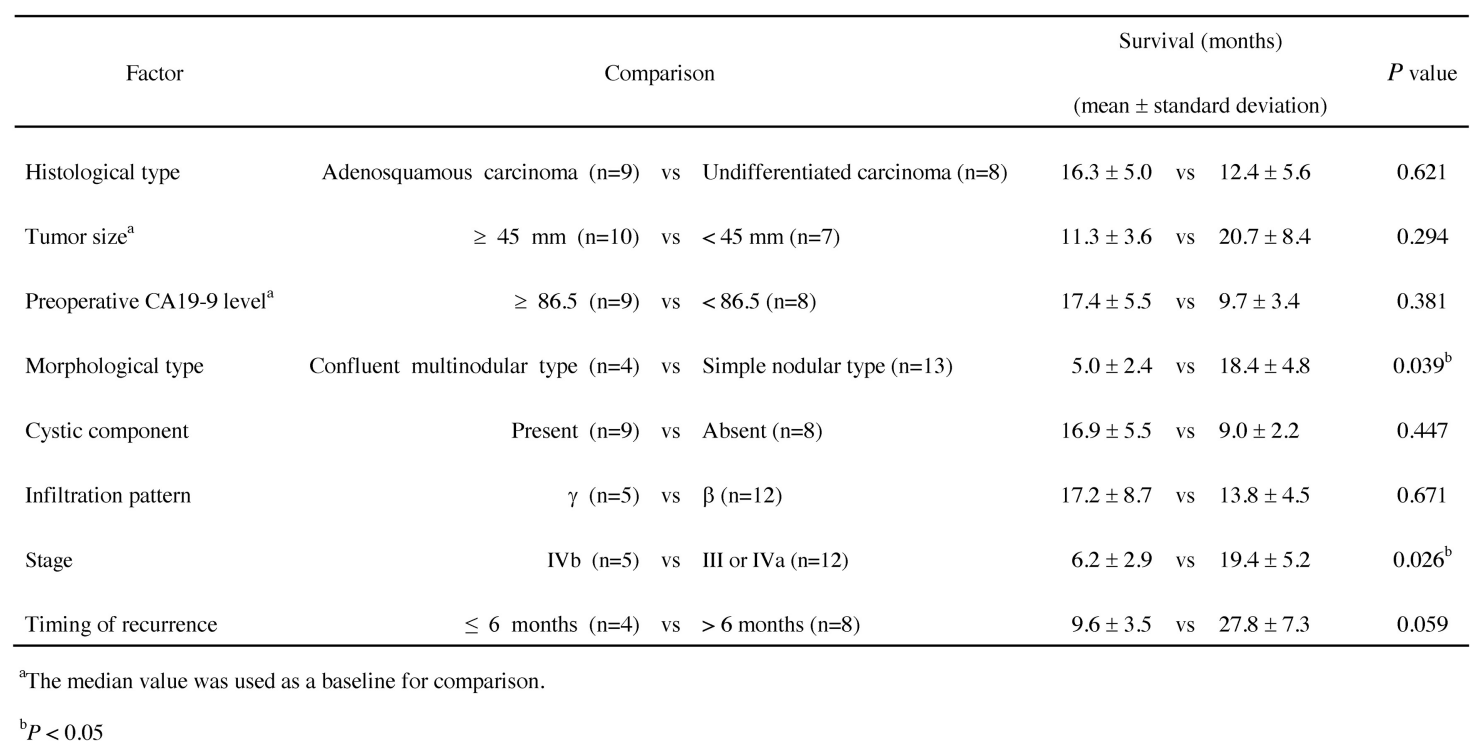

with $\mathrm{ASqC}$ and $\mathrm{UC}$, whereas CK14 staining was positive in 8 of the 9 patients with $\mathrm{ASqC}$ and in 5 of the 8 patients with UC. It has been reported that CK7 is a staining marker for adenocarcinoma, and CK14 is a staining marker for squamous cell carcinoma. Thus, this finding suggests that carcinomas of these histological types maintain the features of adenocarcinoma while differentiating into $\mathrm{ASqC}$ or $\mathrm{UC}$. We experienced a patient who primarily had UC and later had a recurrence of carcinoma in the remaining portion of the pancreas, which was found to be only "common" ductal carcinoma (case no. 14) ${ }^{25}$. Accordingly, these findings suggests that UC can be differentiated from adenocarcinoma cells.

Mean survival was 16.3 months in the patients with pancreatic $\mathrm{ASqC}$ and was 12.4 months in those with UC treated in our hospital. We found that the survival was longer in the patients with stage III and IVa compared to stage IVb cancer, and the survival also tended to be slightly longer in the patients who had recurrence after 6 months. Further more, the patients with a simple-shaped single spherical nodular tumor on imaging survived longer than those with a confluent multinodular type. In our cases, 3 patients (cases2, 3, and 14) survived for 2 years or more. In all 3 of these patients, the tumor stage was earlier (III and IVa), the recurrence was later, and the tumor revealed a simple-shaped single spherical nodular type. Although definitive staging of the tumor and estimation of the timing of relapse are difficult preoperatively, the finding of a simple-shaped single spherical nodular tumor is easily defined preoperatively. At present there is no effective chemotherapy for pancreatic cancer, and surgery is the only treatment offering a cure. Thus, aggressive surgery may provide longer survival in patients with such imaging findings.

\section{References}

1) Aranha GV, Yong S, Olson M. Adenosquamous carcinoma of the pancreas. Int $\mathrm{J}$ Pancreatol 1999; 26: 85-91.

2) Katz MH, Taylor TH, Al-Refaie WB, Hanna MH, Imagawa DK, Anton-Culver H, et al. Adenosquamous versus adenocarcinoma of the pancreas: a population-based outcomes analysis. J Gastrointest Surg 2011; 15: 165-174.

3) Rahemtullah A, Misdraji J, Pitman MB. Adenosquamous carcinoma of the pancreas: cytologic features in 14 cases. Cancer 2003; 99: 372-378.

4) Paal E, Thompson LD, Frommelt RA, Przygodzki RM, Heffess CS. A clinicopathologic and immunohistochemical study of 35 anaplastic carcinomas of the pancreas with a review of the literature. Ann Diagn Pathol 2001; 5: 129 140.

5) Molberg KH, Heffess C, Delgado R, AlboresSaavedra J. Undifferentiated carcinoma with osteoclast-like giant cells of the pancreas and periampullary region. Cancer 1998; 82: 1279-1287.

6) Westra WH, Sturm P, Drillenburg P, Choti MA, Klimstra DS, Albores-Saavedra J, et al. K-ras 
oncogene mutations in osteoclast-like giant cell tumors of the pancreas and liver: genetic evidence to support origin from the duct epithelium. Am J Surg Pathol 1998; 22: 1247-1254.

7) Madura JA, Jarman BT, Doherty MG, Yum MN, Howard TJ. Adenosquamous carcinoma of the pancreas. Arch Surg 1999; 134: 599-603.

8) Kardon DE, Thompson LD, Przygodzki RM, Heffess CS. Adenosquamous carcinoma of the pancreas: a clinicopathologic series of 25 cases. Mod Pathol 2001; 14: 443-51.

9) Ding Y, Zhou J, Sun H, He D, Zeng M, Rao S. Contrast-enhanced multiphasic CT and MRI findings of adenosquamous carcinoma of the pancreas. Clin Imaging 2013; 37: 1054-1060.

10) Boswell JT, Helwig EB. Squamous cell carcinoma and adenoacanthoma of the stomach. A clinicopathologic study. Cancer 1965; 18: 181192.

11) Cook CB, Klickstein GD. Adenoacanthomas of the colon. AMA Arch Pathol 1958; 65: 681687.

12) Smoot RL, Zhang L, Sebo TJ, Que FG. Adenosquamous carcinoma of the pancreas: a single-institution experience comparing resection and palliative care. J Am Coll Surg 2008; 207: 368370.

13) Okabayashi T, Hanazaki K. Surgical outcome of adenosquamous carcinoma of the pancreas. World J Gastroenterol 2008; 14: 6765-6770.

14) Simone CG, Zuluaga Toro T, Chan E, Feely MM, Trevino JG, George TJ Jr. Characteristics and outcomes of adenosquamous carcinoma of the pancreas. Gastrointest Cancer Res 2013; 6: 75-79.

15) Boyd CA, Benarroch-Gampel J, Sheffield KM, Cooksley CD, Riall TS. 415 patients with adenosquamous carcinoma of the pancreas: a population-based analysis of prognosis and survival. J Surg Res 2012; 174: 12-19.

16) Barr RJ, Hancock DE. Adenosquamous carcinoma of the liver. Gastroenterology 1975; 69: 1326-1330.
17) Straus R, Heschel S, Fortmann DJ. Primary adenosquamous carcinoma of the stomach. A case report and review. Cancer 1969; 24: 985-995.

18) Sommers SC, Meissner WA. Unusual carcinomas of the pancreas. AMA Arch Pathol 1954; 58: 101-111.

19) Strobel O, Hartwig W, Bergmann F, Hinz U, Hackert T, Grenacher L, et al. Anaplastic pancreatic cancer: Presentation, surgical management, and outcome. Surgery 2011; 149: 200208.

20) Bergmann F, Esposito I, Michalski CW, Herpel E, Friess H, Schirmacher P. Early undifferentiated pancreatic carcinoma with osteoclastlike giant cells: direct evidence for ductal evolution. Am J Surg Pathol 2007; 31: 1919-1925.

21) Kubo M, Takao S, Shinchi H, Uchikura K, Higashi M, Yonezawa S, et al. Spindle cell carcinoma of the pancreas. J Hepatobiliary Pancreat Surg 2000; 7: 236-241.

22) Maksymov V, Khalifa MA, Bussey A, Carter B, Hogan M. Undifferentiated (anaplastic) carcinoma of the pancreas with osteoclast-like giant cells showing various degree of pancreas duct involvement. A case report and literature review.JOP 2011; 12: 170-176.

23) Machado MA, Herman P, Montagnini AL, Jukemura J, Leite KR, Machado MC. Benign variant of osteoclast-type giant cell tumor of the pancreas: importance of the lack of epithelial differentiation. Pancreas 2001; 22: 105-107.

24) Sun AP, Ohtsuki $Y$, Liang SB, Sonobe H, Iwata J, Furihata M, et al. Osteoclast-like giant cell tumor of the pancreas with metastasis to gallbladder and lymph nodes. A case report. Pathol Res Pract 1998; 194: 587-594.

25) Kobayashi S, Nakano H, Ooike N, Oohashi M, Koizumi S, Otsubo T. Long-term survivor of a resected undifferentiated pancreatic carcinoma with osteoclast-like giant cells who underwent a second curative resection: a case report and review of the literature. Oncol Lett 2014; 8: 14991504. 